\title{
Lactose intolerance: what is a correct management?
}

\section{SUMMARY}

Individuals with Lactose Intolerance (LI) tend to exclude milk from their diet since this behavior seems to relieve the symptoms caused by the disease. However, milk is a food of high nutritional value, and complete exclusion of dairy products may favor the development of bone diseases such as osteopenia and osteoporosis. The objective of this review was to evaluate the scientific evidence on the adequate management of patients with LI. This study was carried out from the review of the scientific literature in PubMed and SciELO databases. Complete exclusion of conventional dairy products is not necessary since most individuals with LI can tolerate up to 12 grams of lactose daily in a single dose. Yogurts and cheeses matured for having low amounts of lactose are part of the strategy that allows consumption of dairy products by patients with LI. Currently, there is a diversity of products considered as "milk substitutes" and supplements aimed at individuals with LI. However, these strategies still require better-designed studies.

KEYWORDS: Lactose intolerance. Lactose. Lactase. Dairy products

\section{INTRODUCTION}

The terms hypolactasia, lactose malabsorption (LMA), lactose intolerance (LI) are usually used as synonyms; however, they have different meanings. ${ }^{1}$ Hypolactasia is the reduction in lactase enzyme activity, which can be classified as a primary, secondary or congenital disability. Some individuals with hypolactasia can present difficulty to digest, and consequently absorb, lactose and are considered poor lactose absorbers. When LAM is associated with the presence of symptoms such as diarrhea, flatulence, abdominal pain and/or abdominal distension, that is characterized as LI. ${ }^{2,3}$

Most individuals with LI usually exclude milk and dairy products from their diet, since this ap- proach seems to mitigate the symptoms caused by the disease. However, it is known that the complete exclusion of such products is not necessary since most of these individuals can tolerate up to $12 \mathrm{~g}$ of lactose in a single dose and have a good tolerance for fermented dairy products. ${ }^{3}$ Cow milk has been widely consumed by populations of several locations for thousands of years. It has a high nutritional value and is a source of several nutrients, such as calcium, a protein of high biological value, magnesium, potassium, selenium and complex B and D vitamins. ${ }^{3-5}$ Thus, the complete exclusion of such food items from one's diet can cause nutritional deficiencies which, in the long term, can

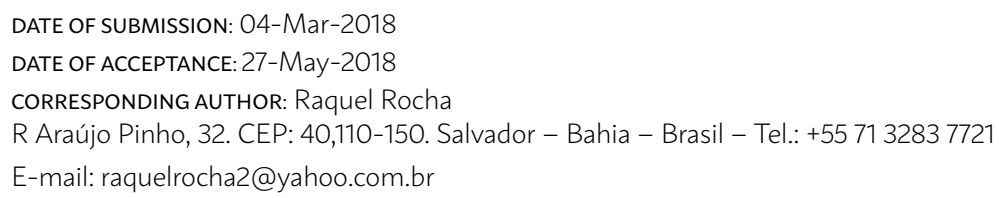


help the onset of bone diseases, in addition to modifying the historical and cultural characteristics of a location. ${ }^{3,4,6}$ Currently, there are several strategies for treating LI; however, there is controversy concerning their effectiveness. ${ }^{3}$ Considering the nutritional and cultural importance of milk and dairy consumption and divergences concerning LI treatment, the objective of this review was to evaluate the scientific evidence on the correct management of patients with this disease.

\section{MANAGING LACTOSE INTOLERANCE}

Individuals with hypolactasia or LMA do not necessarily present the characteristic LI symptoms. Thus, treatment is recommended exclusively to those diagnosed with LI (Figure 1). ${ }^{7}$

The LI treatment will depend on the etiology and is already well defined in the literature. If the LI is a consequence of primary hypolactasia, the consumption of lactose must be temporarily avoided so that there is a remission of the symptoms. ${ }^{3,7,8}$ Most individuals with LI can tolerate up to $12 \mathrm{~g}$ of lactose per day (equivalent to $240 \mathrm{ml}$ of milk) in a single dose. ${ }^{3}$ Thus, milk and dairy products must be reintroduced respecting individual tolerance. ${ }^{8}$ Regular and increasing consumption seems to reduce gastrointestinal symptoms from the bacterial adaptation in the colon, probably due to the increase of beta-galactosidase activity in feces. Nonetheless, results are still conflicting. ${ }^{9}$

If the LI is a consequence of secondary hypolactasia, all food that contains lactose must be temporarily excluded until the underlying disease is controlled. ${ }^{8}$ It is noteworthy that individuals with diseases that affect the digestive tract, such as inflammatory bowel disease, will not necessarily develop LI. Thus, the exclusion of such foods must not be generalized. ${ }^{10}$

Some changes in diet can be helpful in improving lactose tolerance, such as portioning the daily amount of milk consumption into smaller doses, ingesting it with other foods, and ingesting fermented and matured dairy products, which naturally have low amounts of lactose. ${ }^{8}$

Individuals with a congenital lactase deficiency must exclude lactose from their diet permanently. ${ }^{7}$

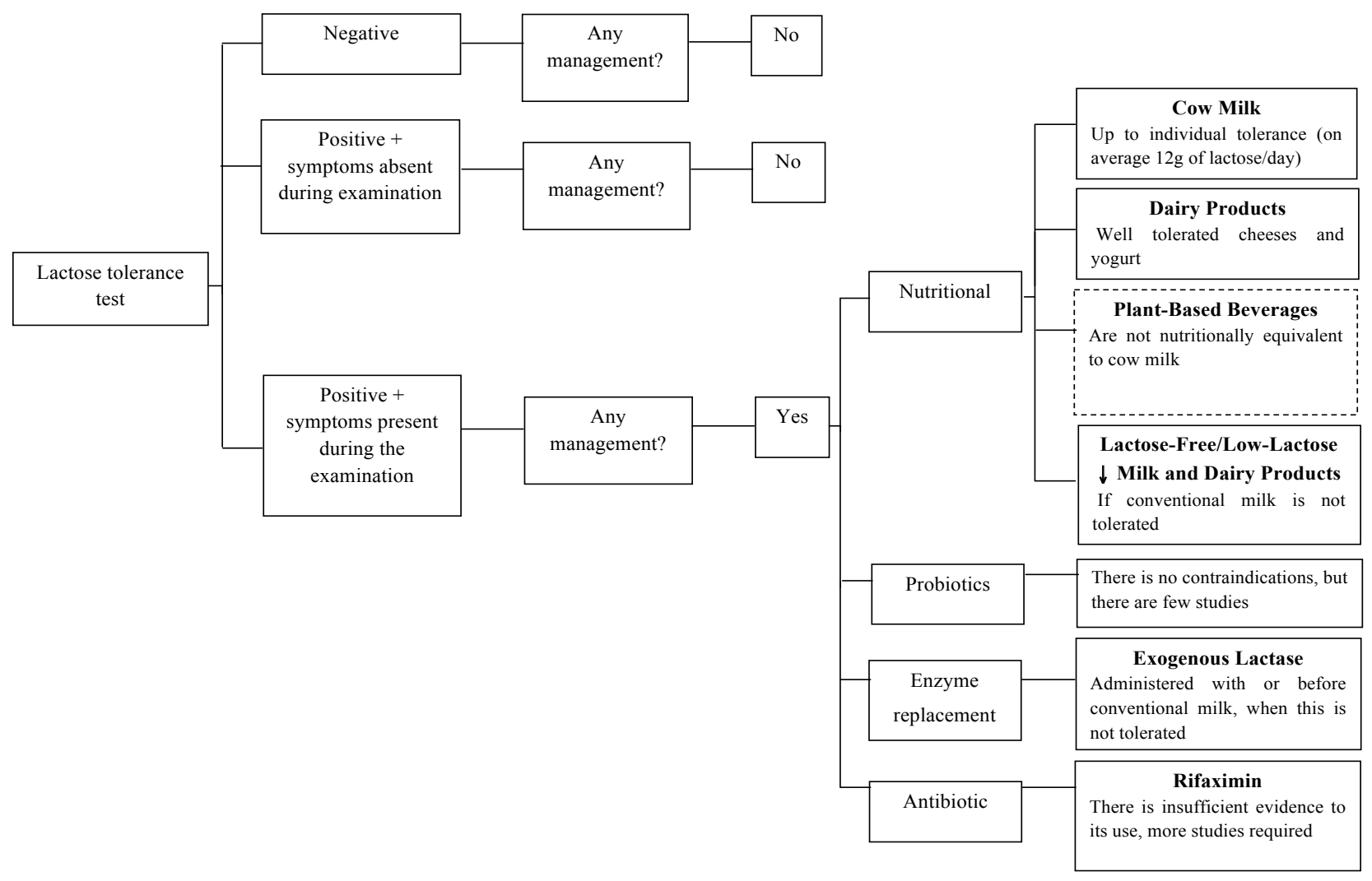




\section{COW MILK}

Cow milk is one of the primary sources of lactose. It has several nutrients, especially proteins with high biological value, bioavailable calcium and vitamin D for fortification. Thus, its permanent exclusion from one's diet can result in nutritional deficiencies, with a predisposition to the development of osteopenia and osteoporosis. ${ }^{3,6,11}$ Although there are other sources of calcium, milk is one of the foods with a higher concentration and a high absorption rate of the nutrient. The high bioavailability of calcium in cow milk and in its products is attributed to the presence of lactose, caseinate, and citrate. ${ }^{12}$

According to the Food Pyramid adapted to the Brazilian population, in order to reach ideal levels of protein and calcium, it is recommended that healthy individuals consume three daily servings of dairy products. ${ }^{13,14}$ Thus, they should be supplemented with calcium and vitamin D. ${ }^{8,15}$ However, the effectiveness of ingesting this nutrient from non-dairy products and supplements must be evaluated concerning bone health. ${ }^{3}$ Also, the isolated supplementation of calcium seems to be linked with the presence of gastrointestinal symptoms, kidney stone diseases, and other clinical complications. ${ }^{16}$

Nonetheless, these nutritional strategies may not be enough to improve LI symptoms. ${ }^{15}$ As a result, the industry has produced supplements, medication, and food products targeted at this audience with the purpose of improving lactose tolerance.

\section{DAIRY PRODUCTS}

Dairy products derive from cow milk and usually present lower amounts of lactose. ${ }^{17}$ One of the most widely consumed is yogurt, which comes from cow milk and is pasteurized, homogenized and added with two bacteria: Streptococcus thermophilus and Lactobacillus Bulgaricus. ${ }^{18}$ These bacteria are capable of fermenting lactose, transforming it into lactic acid. ${ }^{19,20}$ The amount of lactose present in 200 $\mathrm{ml}$ of yogurt is lower than what is usually tolerated (12 grams); that is why its consumption must be encouraged. ${ }^{3,19}$ Some factor might influence the lactose amount in these products, such as the effectiveness of the bacterial lactase, resistance to gastric acidity, expiration date, and storage temperature. ${ }^{19}$

Like yogurt, cheese is a fermented dairy product that can be classified as fresh or matured. The first is ready for consumption right after production, while the second must go through biochemical and physical exchanges that are characteristics of each type. ${ }^{21}$ Most lactose is found in milk whey, and cheese is made of, basically, of the solid portion, which makes it a dairy product with low amounts of lactose. Also, during the process of maturation, lactose is metabolized by lactic acid bacteria, which is why the final amount of lactose in maturated cheese is minimal. ${ }^{22}$ Some cheeses, such as mozzarella, have only traits of lactose. ${ }^{17}$

\section{PLANT-BASED BEVERAGES}

Some individuals with LI consume plant-based beverages as an alternative, ${ }^{23}$ since they are lactose-free. Their production process consists in extracting plant material in water and subsequently homogenizing it, which gives the liquid a milk-like texture and appearance. ${ }^{24}$

Most plant-based beverages have low levels of calcium and other nutrients. This nutritional deficit usually is related to the presence of antinutritional factors and the loss of nutrients during the heating process. Thus, this type of beverage should not be considered a suitable replacement for cow milk. ${ }^{24}$ In addition to the low level of calcium, ${ }^{25}$ soy-based beverages, one of the most widely consume types, have a poor acceptance due to its unpleasant taste, astringent and bitter, similar to "raw or green beans". ${ }^{26}$

In order to minimize or mitigate these problems, the industry has been using different techniques, such as adding enzymes to break the antinutrients, ${ }^{27}$ adding micronutrients ${ }^{24,25}$ and other additives, such as juices, fruit extracts, and sucrose to improve palatability. ${ }^{28}$ However, the bioavailability of these nutrients and the effects of adding such products are not evident yet.

\section{LACTOSE-FREE/LOW-LACTOSE MILK AND DAIRY PRODUCTS}

Over the past years, the production of lactose-free or low-lactose food has been growing due to the desire to service individuals with LI and compensate for market losses due to a decrease in the consumption of the traditional products. ${ }^{29}$

In the industry, there are several methods for making this type of milk, and hydrolysis with soluble enzymes is considered the most simple one since it does not require special equipment. Despite the 
TABLE 1 - NUTRITIONAL COMPOSITION OF CONVENTIONAL AND LACTOSE-FREE MILK

\begin{tabular}{|c|c|c|c|c|c|c|c|c|c|}
\hline \multirow[t]{2}{*}{ Brands } & \multirow[t]{2}{*}{$\begin{array}{l}\text { Nutritional com- } \\
\text { position }\end{array}$} & \multicolumn{2}{|c|}{$\begin{array}{l}\text { Whole milk powder } \\
\text { (100 g) }\end{array}$} & \multicolumn{2}{|c|}{ Whole milk (100 ml) } & \multicolumn{2}{|c|}{$\begin{array}{l}\text { Skim milk powder } \\
(100 \mathrm{~g})\end{array}$} & \multicolumn{2}{|c|}{ Skim milk (100 ml) } \\
\hline & & Traditional & $\begin{array}{l}\text { Zero } \\
\text { lactose }\end{array}$ & Traditional & $\begin{array}{l}\text { Zero } \\
\text { lactose }\end{array}$ & Traditional & $\begin{array}{l}\text { Zero } \\
\text { lactose }\end{array}$ & Traditional & $\begin{array}{l}\text { Zero } \\
\text { lactose }\end{array}$ \\
\hline \multirow{5}{*}{ Brand 1} & Protein (g) & 25.77 & 25.77 & 3.30 & 3.30 & 34.5 & - & 3.20 & 3.20 \\
\hline & Carbohydrates (g) & 36.92 & 36.92 & 4.40 & 4.40 & 50.0 & - & 5.00 & 5.00 \\
\hline & Lactose (g) & - & 0.00 & - & 0.00 & - & - & - & 0.00 \\
\hline & Lipids (g) & 27.31 & 27.31 & 3.30 & 3.30 & 0.00 & - & 0.00 & 0.00 \\
\hline & Calcium (mg) & 919.23 & 919.23 & 115.00 & 115.00 & 1300 & - & 130.00 & 130.00 \\
\hline \multirow[t]{5}{*}{ Brand 2} & Protein (g) & 26.15 & - & 3.30 & 3.30 & 34.50 & - & 3.40 & 3.40 \\
\hline & Carbohydrates (g) & 38.46 & - & 4.70 & 4.70 & 50.00 & - & 4.85 & 4.85 \\
\hline & Lactose (g) & - & - & 4.70 & 0.00 & - & - & 4.85 & 0.00 \\
\hline & Lipids (g) & 26.54 & - & 3.10 & 3.10 & 0.00 & - & 0.00 & 0.00 \\
\hline & Calcium (mg) & 911.54 & - & 119.00 & 119.00 & 2500 & - & 150.00 & 150.00 \\
\hline \multirow[t]{5}{*}{ Brand 3} & Protein (g) & 26.15 & $18.08^{*}$ & 3.20 & 3.20 & 33.50 & $26.40^{*}$ & 3.20 & 3.20 \\
\hline & Carbohydrates (g) & 38.08 & 57.69 & 4.90 & 4.90 & 50.00 & 60.00 & 5.00 & 5.00 \\
\hline & Lactose (g) & - & 0.00 & - & 0.00 & - & 0.00 & - & 0.00 \\
\hline & Lipids (g) & 26.92 & 18.85 & 3.45 & 3.45 & 0.00 & 0.00 & 0.40 & 0.40 \\
\hline & Calcium (mg) & 946.15 & 734.62 & 119.00 & 119.00 & 2500.00 & 2000.00 & 167.00 & 167.00 \\
\hline
\end{tabular}

Source: Product label ${ }^{34}{ }^{\star}$ Milk Composite.

low production costs, skim milk powder produced using this method does not have good acceptance by the consumers, since it has accentuated sweetness, besides being more prone to the Maillard reaction, which causes darkening and reduction of the nutritional value (deterioration of proteins) and changes in smell. ${ }^{31}$

In Brasil, until 2016, there was no legislation determining the maximum lactose allowed in such products and defining the expressions used in labels. That is why there is great variation in the information contained in labels and the actual amount of lactose in the product, which can lead the consumer to purchase products that do not meet their individual needs, especially of those with severe intolerance. Two resolutions concerning the labeling of food containing lactose, RDC135/2017, and RDC136/2017, were published in Brasil. Manufacturers will be required to add the words "contém lactose" [contains lactose] on the label of products containing over $0.1 \%$ of lactose. ${ }^{32}$ The expressions "Zero Lactose", "Isento de Lactose" [Lactose Free], "O\% Lactose", "Sem Lactose" [No Lactose] ou "Não Contém Lactose" [Does Not Contain lactose] can be added to products with a lactose content equal to or lower than $100 \mathrm{mg} / 100$ $\mathrm{g}$ or $\mathrm{ml}$. Those with contents over $100 \mathrm{~g}$ and lower than or equal to $1 \mathrm{~g}$ can have the expressions "Baixo Teor de Lactose" [Low Lactose Content] or "Baixo em Lactose" [Low Lactose] on the label. These last regulations must be complied with by the end of $2019 .{ }^{33}$
In the Brazilian market, there are several types of Ultra High Temperature (UHT) milk that are lactose-free or have low amounts of lactose, with no differences in nutritional content in comparison with conventional milk, according to the information contained on the label. In contrast, there are not many options of milk powder - most are a type of milk composite ${ }^{*}$ - that have lower amounts of macronutrients and calcium (Table 1). That is why it is essential to, when recommending replacing conventional milk for a low-lactose or lactose-free substitute, the nutritionist must now the macro- and micronutrient composition of different brands, choosing the best products with the purpose of avoiding adverse impacts on the diet. These products have a calcium content similar to that of traditional products; however, there are few data about the effects of its consumption on bone mineral density in individuals with LI. Furthermore, there is insufficient evidence concerning their ingestion and the symptoms associated with the disease. They are usually more expensive products, costing up to $71.9 \%$ more than the lactose version of the same product, ${ }^{34-36}$ so it is not something accessible to everyone.

\section{PROBIOTICS}

Probiotics are "living microorganisms capable of improving the intestines microbial balance, produc- 
ing beneficial effects on health. ${ }^{\text {37 }}$ These microorganisms contain beta-galactosidase, which can contribute to the digestion of lactose in individuals with LI. ${ }^{38}$

Although recent studies show an improvement in LI symptoms after supplementation with Lactobacillus Acidophilus ${ }^{39}$ and the combined use of Lactobacillus casei Shirota e Bifidobacterium Breve, ${ }^{40}$ the use of probiotic for managing LI is not well established since the studies available have limitations in sample size, different inclusion criteria, types, sources, and concentrations of different probiotics. ${ }^{34}$

\section{ENZYME REPLACEMENT THERAPY WITH EXOGENOUS LACTASE}

The exogenous lactase enzyme, usually obtained from fungi or yeasts, acts as the natural lactase that is missing or with low activity. Such enzymes can be administered with milk or in the form of capsules, pills, or liquids before the intake of dairy products. The hydrolysis ability of the lactase depends on its origin, and enzyme activity is different for every commercial product. ${ }^{41}$

When evaluating the effectiveness of supplementation with this enzyme, some authors found a reduction of expired hydrogen and improvement of LI symptoms. ${ }^{42,43}$ However, the supplement is not capable of fully hydrolyzing the lactose, with different results in each individual. ${ }^{15}$ There are reports on the association of lactase supplements and allergic reactions and anaphylaxis. ${ }^{44}$ Thus, more studies are needed to evaluate lactase and its hydrolysis ability in order to ensure more safety when using this supplement.

\section{RIFAXIMIN}

Rifamixin is a broad-spectrum antibiotic capable of destroying anaerobic bacteria that ferment lactose, producing hydrogen, carbon dioxide, and methane. ${ }^{45}$ It is believed that LI symptoms are related to the composition of the intestinal microbiota since different bacteria metabolize lactose in different ways. ${ }^{46}$ Thus, the use of this antibiotic could contribute to the treatment of LI. ${ }^{47}$

Some authors have shown that the use of this drug reduced the production of hydrogen and gastrointestinal symptoms in individuals with LI. ${ }^{47} \mathrm{Howev-}$ er, the evidence available is insufficient for using this antibiotic in the management of the disease. ${ }^{34}$ Since its effectiveness has been proved, it is necessary to perform studies with prolonged administration of rifaximin and monitoring for a more extended period, to meet the need of this population. ${ }^{47}$

\section{CONCLUSION}

Excluding milk and dairy products from the diet of LI patients is not recommended in general, considering such products can be tolerated using some diet strategies. This would allow the maintenance of palatability of food preparations, cultural habits, and adequate nutritional supply. In order to assure an improved tolerance in these patients, some therapeutic strategies have emerged; however, its benefits and safety are still unclear. Given this scenario, we need scientific studies to evaluate the effectiveness and safety of these strategies, including an investigation of the nutritional composition and bioavailability of nutrients in plant-based beverages and lactose-free milks.

\section{RESUMO}

Os indivíduos com Intolerância à Lactose (IL) tendem a excluir o leite da alimentação, uma vez que essa conduta parece aliviar os sintomas ocasionados pela doença. Entretanto, o leite é um alimento de alto valor nutricional e a exclusão completa dos laticínios pode favorecer o desenvolvimento de doenças ósseas como osteopenia e osteoporose. O objetivo desta revisão foi avaliar as evidências científicas sobre o manejo adequado de pacientes com IL. Este estudo foi realizado a partir da revisão da literatura científica nas bases de dados PubMed e SciELO. A exclusão completa dos produtos lácteos convencionais não é necessária, pois a maior parte dos indivíduos com IL consegue tolerar diariamente até $12 \mathrm{~g}$ de lactose em uma única dose. Os iogurtes e queijos maturados, por terem baixa quantidade de lactose, fazem parte da estratégia que garante consumo de produtos lácteos por pacientes com IL. Atualmente existe uma diversidade de produtos considerados "substitutos do leite" e suplementos voltados para os indivíduos com IL, no entanto, essas estratégias ainda requerem estudos mais bem desenhados.

PALAVRAS-CHAVE: Intolerância à lactose. Lactose. Lactase. Laticínios.

\section{REFERENCES}

1. Jellema P, Schellevis FG, van der Windt DA, Kneepkens CM, van der Horst $\mathrm{HE}$. Lactose malabsorption and intolerance: a systematic review of the diagnostic value of gastrointestinal symptoms and self-reported milk intolerance. QJM. 2010;103(8):555-72.
2. Wortmann AC, Simon D, Silveira TR. Análise molecular da hipolactasia primária do tipo adulto: uma nova visão do diagnóstico de um problema antigo e frequente. Rev AMRIGS. 2013:57(4):335-43.

3. Suchy FJ, Brannon PM, Carpenter TO, Fernandez JR, Gilsanz V, Gould JB, 
et al. NIH consensus development conference statement: lactose intolerance and health. NIH Consens State Sci Statements. 2010;27(2):1-27.

4. Benevides IA, Veigas A. Aspectos históricos, fisiológicos e antroposóficos do leite na alimentação humana: uma introdução ao tema. Arte Méd Ampl. 2014;34(1):5-12.

5. Food and Agriculture Organization of the United Nations. Milk and dairy products in human nutrition. Rome: Food and Agriculture Organization; 2013.

6. Salomão NA, Silva TA, Geraldes AAR, Lima-Silva, AE. Ingestão de cálcio e densidade mineral óssea em mulheres adultas intolerantes à lactose. Rev Nutr. 2012;25(5):587-95.

7. Lomer MC, Parkes GC, Sanderson ID. Review article: lactose intolerance in clinical practice-myths and realities. Aliment Pharmacol Ther. 2008;27(2):93-103.

8. Montalto M, Curigliano V, Santoro L, Vastola M, Cammarota G, Manna $R$, et al. Management and treatment of lactose malabsorption. World ] Gastroenterol. 2006;12(2):187-91.

9. Briet F, Pochart P, Marteau P, Flourie B, Arrigoni E, Rambaud IC. Improved clinical tolerance to chronic lactose ingestion in subjects with lactose intolerance: a placebo effect? Gut. 1997;41(5):632-5.

10. Baños Madrid R, Salama Benerroch H, Morán Sánchez S, Gallardo Sánchez F, Albadalejo Meroño A, Mercader Marrtínez |. Lactose malabsorption in patients with inflammatory bowel disease without activity: would it be necessary to exclude lactose products in the diet of all patients? A Med Intern. 2004;21(5):212-4.

11. Buzinaro EF, Almeida RNA, Mazeto GMFS. Biodisponibilidade do cálcio dietético. Arq Bras Endocrinol Metab. 2006;50(5):852-61.

12. Grüdtner VS, Weingrill $P$, Fernandes AL. Aspectos da absorção no metabolismo do cálcio e vitamina D. Rev Bras Reumatol. 1997;37(3):143-51.

13. Philippi ST. Pirâmide dos alimentos. Fundamentos básicos da nutrição. Barueri: Manole; 2013.

14. Sociedade Brasileira de Alimentação e Nutrição. A importância do consumo de leite no atual cenário nutricional brasileiro. 2015. [cited 2018 Feb 12]. Available from: http://sban.cloudpainel.com.br/source/SBAN_Importancia-do-consumo-de-leite.pdf

15. Mattar R, Mazo DFC. Intolerância à lactose: mudança de paradigmas com a biologia molecular. Rev Assoc Med Bras. 2010;56(2):230-6.

16. Harvey NC, Biver E, Kaufman JM, Bauer J, Branco J, Brandi ML, et al. The role of calcium supplementation in healthy musculoskeleta ageing: An expert consensus meeting of the European Society for Clinical and Economic Aspects of Osteoporosis, Osteoarthritis and Musculoskeletal Diseases (ESCEO) and the International Foundation for Osteoporosis (IOF). Osteoporos Int. 2017;28(2):447-62.

17. US Department of Agriculture, Agricultural Research Service (USDA-ARS), 2015. USDA National Nutrient Database for Standard Reference, Release 28.

18. Robert NF. Fabricação de iogurtes: dossiê técnico. Serviço Brasileiro de Respostas Técnicas, 2008. [cited 2018 Feb 13]. Available from: http://respostatecnica.org.br/dossie-tecnico/downloadsDT/Mzlw

19. Borges T, Ferreira I, Pinho O, Trindade E, Pissarra S, Amil J. Quanta lactose há no meu iogurte? Acta Pediatr Port. 2010;41(2):75-8.

20. Savaiano DA. Lactose digestion from yogurt: mechanism and relevance. Am | Clin Nutr. 2014;99(5 Suppl):1251S-5S.

21. Brasil. Ministério da Agricultura, Pecuária e Abastecimento. Portaria $n^{0}$ 146, de 07 de Março de 1996. Aprova os regulamentos técnicos de identidade e qualidade dos produtos lácteos. Diário Oficial da República Federativa do Brasil, Poder Executivo, Braślia, DF, 07 de Março de 1996, Seção 1 p.3977.

22. McSweeney PLH. Biochemistry of cheese ripening. Int | Dairy Technol. 2004;57.

23. Fourreau D, Peretti N, Hengy B, Glillet Y, Courtil-Teyssedre S, et al. Complications carrentielles suite a l'utilisation de laits vegetaux, chez de nourrisons de deux mois et demi à 14 mois. La Presse Médicale. 2013;42.

24. Sethi S, Tyaqi SK, Anuraq RK. Plant-based milk alternatives an emerging segment of functional beverages: a review. I Food Sci Technol. 2016;56(9):3408-23

25. Casé F, Deliza R, Rosenthal A, Mantovani D, Felberg I. Produção de 'leite' de soja enriquecido com cálcio. Ciênc Tecnol Aliment. 2005;25(1):86-91.

26. Yang A, Smyth H, Chaliha M, James A. Sensory quality of soymilk and tofu from soybeans lacking lipoxygenases. Food Sci Nutr. 2016;4(2):207-15.
27. Zhang H, Onning G, Triantafyllou AO, Oste R. Nutritional properties of oat-based beverages as affected by processing and storage. J Sci Food Agric. 2007:87(12):2294-301.

28. Barbosa EG. Prevalência de bactéria probiótica L. acidophilus - NCFM em extrato de soja fermentado e saborizado com sacarose e polpa de pêssego [dissertação]. Pelotas: Faculdade de Agronomia Eliseu Maciel, Universidade Federal de Pelotas; 2007

29. Jelen $P$, Tossavainen $O$. Low lactose and lactose-free milk and dairy products - prospects, technologies and applications. Aust | Dairy Tech. 2003;58(2):161-5

30. Harju M., Kallioinen $H$, Tossavainen $\mathrm{O}$. Lactose hydrolysis and other conversions in dairy products: technological aspects. Int Dairy J. 2012;22(2):104-9.

31. Naranjo GB, Pereyra Gonzales AS, Leiva GE, Malec LS. The kinetics of Maillard reaction in lactose-hydrolysed milk powder and related systems containing carbohydrate mixture. Food Chem. 2013;141(4):3790-

32. Brasil. Ministério da Saúde. Agência Nacional de Vigilância Sanitária. RDC no 135 de 8 de Fevereiro de 2017. Altera a Portaria SVS/MS no 29, de 13 de janeiro de 1998, que aprova o regulamento técnico referente a alimentos para fins especiais, para dispor sobre os alimentos para dietas com restrição de lactose. Diário Oficial da República Federativa do Brasil, Poder Executivo, Brasília, 8 de Fev.2017.

33. Brasil. Ministério da Saúde. Agência Nacional de Vigilância Sanitária. RDC no 136 de 8 de Fevereiro de 2017. Estabelece os requisitos para declaração obrigatória da presença de lactose nos rótulos dos alimentos. Diário Oficial da República Federativa do Brasil, Poder Executivo, Brasília, 8 de Fev.2017.

34. Shaukat A, Levitt MD, Taylor BC, MacDonald R, Shamliyan TA, Kane RL, et al. Systematic review: effective management strategies for lactose intolerance. Ann Intern Med. 2010;152(12):797-803.

35. Pão de Açúcar. [cited 2017 Mar 26]. Available from: <http://busca.paodeacucar.com/ppc/leite>

36. Extra. [cited 2017 Mar 26]. Available from: < http://buscando.extra.com $\mathrm{br} /$ ?strBusca=leite\&Filtro=>

37. Brasil. Resolução RDC no 2, de 07 de janeiro de 2002. Aprova o regulamento técnico de substâncias bioativas e probióticos isolados com alegação de propriedades funcional e ou de saúde. Diário Oficial [da] República Federativa do Brasil, Brasília, DF, 09 jan. 2002.

38. Heaney RP. Dairy intake, dietary adequacy, and lactose intolerance. Adv Nutr. 2013;4(2):151-6

39. Pakdaman MN, Udani JK, Molina JP, Shahani M. The effects of the DDSstrain of lactobacillus on symptomatic relief for lactose intolerance: a randomized, double-blind, placebo-controlled, crossover clinical trial. Nutr ]. 2016;15(1):56

40. Almeida CC, Lorena SL, Pavan CR, Akasaka HM, Mesquita MA. Beneficial effects of long-term consumption of a probiotic combination of Lactobacillus casei Shirota and Bifidobacterium breve Yakult may persist after suspension of therapy in lactose-intolerant patients. Nutr Clin Pract. 2012;27(2):247-51.

41. laniro G, Pecere S, Giorgio V, Gasbarrini A, Cammarota G. Digestive enzyme supplementation in gastrointestinal diseases. Curr Drug Metab. 2016;17(2):187-93

42. Francesconi CF, Machado MB, Steinwurz F, Nones RB, Ouilici FA, Catapani WR, et al. Oral administration of exogenous lactase in tablets for patients diagnosed with lactose intolerance due to primary hypolactasia. Arq Gastroenterol. 2016;53(4):228-34.

43. Ibba I, Gilli A, Boi MF, Usai P. Effects of exogenous lactase administration on hydrogen breath excretion and intestinal symptoms in patients presenting lactose malabsorption and intolerance. Biomed Res Int. 2014;2014:680196.

44. Voisin MR, Borici-Mazi R. Anaphylaxis to supplemental oral lactase enzyme. Allergy Asthma Clin Immunol. 2016;12:66.

45. Gastrointestinal Drugs Advisory Committee. Xifaxan ${ }^{\circledast}$ (Rifaximin) Tablets, 550 mg, NDA 22-554: briefing document for Gastrointestinal Drugs Advisory Committee Meeting, 23 February 2010. Food and Drug Administration 2010.

46. Zhong Y, Priebe MG, Vonk R|, Huang CY, Antoine |M, He T, et al. The role of colonic microbiota in lactose intolerance. Dig Dis Sci. 2004;49(1):78-83.

47. Cappello G, Marzio L. Rifaximin in patients with lactose intolerance. Dig Liver Dis. 2005;37(5):316-9. 